\title{
Editorial: Beyond Us and Them: Migration and global economic development
}

\author{
WENDY HARCOURT
}

Development has devoted three journals to the issue of migration. The first in March 1993 was on 'Immigration and the Division of Labour'. The second, on 'Migration, Citizenship, Identity and Rights', was published in September 2003. This third issue, out in December 2007, picks up the debate again looking at how migration is deeply integrated into the workings of the global market in ways that the international development community cannot ignore.

The first journal in 1993 somewhat optimistically suggested that sound development policy could ensure a more balanced world economy, thereby diminishing the need for a mass movement of people. The articles spoke confidently of sustainable development, of equalizing patterns of North-South economic development, of global solidarity with refugees and migrants, of southern governments avoiding South-North migration by making their economies more attractive to workers. There was little talk of permanent movement or disruption, nor did it seem conceivable that displacement and migration could become a way of life for the poor in an endless search for economic, social and political security.

A decade later, in 2003, the focus shifted to the down side of economic and social trends for the majority of migrants, refugees and displaced people. Migration was viewed as an inevitable, unstoppable part of the modern global world that was in many ways undermining workers' rights. Increased competition, rapid technological change and the decline of the organized manufacturing sector had led to an unprecedented expansion of the informal sector, creating an increasing demand for cheap, unorganized and often irregular, immigrant workers. The 2003 journal discussions looked at the rights of migrants, refugees and displaced people within their new environment and possibly permanent sense of loss of home, identity and citizenship rights. The articles pointed to the growing racism and xenophobia, harsh conditions, violence, ill health and vulnerability faced by all types of migrants, refugees and displaced people in the North and the South.

This third issue of Development to tackle migration, just four years later, focuses even more on such realities and fears, as we struggle to understand the huge impact of global migration on development policy. The hundreds of millions of people who have crossed borders in search of jobs or a new life do not constitute 'problems' to be solved by more 
balanced economic growth or by better integration and services in the 'receiving' country, or by adherence to rights. Development policy has to face the reality that migration issues stem from what Lourdes Arizpe in her lead article calls the 'failed societies' that migrants are leaving behind. These failures are related to the larger issue of transnational global capital and its impact on the nation, citizenship and governance.

The first message of the journal is that at both the international and the domestic level movements of people are an integral feature of globalization. The nexus between migration and development needs to be viewed through the complex lens of globalization, market demand and the insecurity of the national state. If we do not take on board the changes required for development policy, the rights and legitimacy of migrants will remain compromised. But it is not enough to talk about state responses nor hold high-level roundtables on the side. The complexities posed by transnational movements of people (whether within the South or South-North or East-West) demand transnational responses and analysis. In this sense, development needs to move out of old nation bound frameworks that do not reflect transnational realities. Whether or not we agree with UNCTAD Secretary General Rubens Ricupero that "migration is the missing link between globalization and development' (Marshall and Thatun, 2005: 55), it is clear that the implications of migration need to be much sharper in development policy discussions. As the articles show, development needs to catch up with the reality of transnational migration. First, because of the numbers involved in the flows of people migrating across borders point to major discontents, and second, because the large flows of remittances from the migrants that go to communities back home begin to rival development aid contributions in size, importance and effectiveness. The impact of migration is far from insignificant in relation to development goals and aims and yet decisions about where people are going, what jobs they take up and where the money they send back home is spent are outside the sphere of formal development
An entire section of the journal is devoted to sub-Saharan Africa, where widespread inequality, deepening poverty and the liberalization of markets are contributing to massive levels of migration and many communities back home are depending on remittances for their survival. The journal features some of the studies by the Society for International Development and its partner CeSPI (Centre for the Study of International Politics) in Africa that has examined European policy responses to African migration flows. The study shows how remittances are becoming a major focus of development institutions and that migration is not a random individual choice. People who migrate are highly organized and travel well-worn paths. The articles explain how economic and political conditions have led to huge numbers of sub-Saharan African communities migrating mostly within Africa but also to Europe in order to secure their and their communities' livelihoods with varying degrees of success. They map out how a better understanding of the migration and development nexus including remittances could encourage South-North and South-South social and economic relations with more open and accountable development paths.

The second message of the journal is that development pathways that take into account migration needs are not clear, because the numbers of people on the move and the failure to respond to their needs call into question basic assumptions around nation, citizenship and governance. Unlike the early 1990s where there was the blithe assumption that national economic and social policy could respond to citizens' needs, in today's world migration and development are intertwined in a far more complex set of transnational realities. In 2007, we see that the pathways for economic stability have not materialized as hoped through international trade and foreign direct investment. Not only are there 200 million poor people who leave home under often desperate circumstances to look for a new life, but skilled workers are also on the move. Development policies have not managed to reduce the technology gap and diversify the economy to encourage skilled labour to stay. A recent UNCTAD report shows that in 2004, 15 percent of trained 


\section{Harcourt: Editorial: Beyond Us and Them}

people had emigrated out of the poorest countries (Balakrishnan and Man, 2007).

We are living in a world where the state is failing to cope with the complex political-economic realities of a globalizing world. As a result, many migrants find themselves outside of national or international legal, social and financial norms as the rules that govern their lives can no longer be met by state economic and political policy. These realities are challenging concepts of citizenship, trans-national borders, diversity, social protection and security. As Gillian Youngs states in her recently published book Global Political Economy in the Information Age: Power and Inequality: "we are living in a time of great tension between the established national limits to our political thinking and the transnational characteristics of globalization' (Youngs, 2007: 80).

Today's development discussions on empowerment, democracy, civil society and good governance point to reconfigured global workings of power marked by a shrinking state, together with the emergence of flexible capitalism at supranational levels. The sovereignty of the state is now partially invested in supranational and non-governmental organizations. Many functions traditionally tied to the state are being carried out by non-governmental organizations that do not necessarily operate within a national structure and whose accountability is at times questionable. National spaces are now crisscrossed by transnationally defined activities. These shifts have reduced ways for states in the South to secure their sovereignty and defend their borders, which are now porous in highly unequal ways both in relation to transnational corporations and people. Citizenship itself is becoming transnationally administered and exercised. Governments are not simply governing national populations that live within their territories but are claiming and managing populations that no longer live or have never lived within their territories. The emergent transnational economic order is not only reshaping the global labour map but also reshaping the relationship between citizenship, national identity and the state.

The third message of the journal is that we need to go deeper into what is happening culturally and socially in order to understand how the world is being transformed by migration. At the core of these transformations have been shifts in gender relations. As the articles by Laura Agustín on sex work, Lourdes Arzipe on Mexican migrants, Flavia Piperno on East European care drain and Gale Summerfield on migrant workers in the US show, the impact of migration on families, communities and specifically on women's gendered caring roles are under tremendous pressure. They underline how the process of global migration is experienced quite differently for men and women. Summerfield estimates that 49.6 percent of transnational migrants are women tied into globalized processes of exporting their labour power. The numbers of women now engaged in migration, whether in export trade zones, care work, domestic services or sex work, have feminized large sections of the work force in new ways. The social and psychological changes between men and women as women take on new roles outside the home and community have to be understood in terms that go beyond economic loss or gain. Mexican women migrants, according to Arizpe, despite the hardships, see American cultural values as more positive for women, with less drinking and machismo, crime and drugs than in Mexico. Flavia Piperno points out that Eastern European women continue to provide care even while abroad so that their caring role is stretched across borders. Their role as welfare providers is not only for the young, old and ill in their place of work but also at home as they undertake long-distance parenting and caring. Such realities need to be recognized if we are to limit the negative impact of care drain for some at the cost of the care gain for others.

The rate of abuse, domestic violence and crime associated with women on the move is often in the public eye. Monzini (2005), in her study on Sex Traffic, estimates that there are 50 million expatriate women and girls involved in the legal and illegal global sex market with daily news stories about the abuse of women's bodies, through trafficking and sexual slavery. Cawa Abdi, in her article on Somali refugees, points to differential gender experiences in conflict zones and occupied territories where women and girl refugees in conflict zones are subjected to sexual violence and abuses of occupying forces as well as in several 
documented cases international peacekeeping personnel. Alison Crosby in her article on migration categorization, however, underlines that it is important to look at the economic exploitation and social marginalization that leads people to situations where they are trafficked, and the implication of northern economic interests in these situations. She warns that fears of sexual harm can become reasons to restrain women's movement. Along with Agustín, she underscores that women's own motivations to move need to be recognized and respected. Agustin points out that migration is not entirely a negative phenomenon; for some, it is a welcome choice to leave home.

Violence as experienced by migrants has not only a gender but a racist, highly dangerous dimension. Brian Murphy describes how the anti-immigrant faction in North America and West Europe with its "underlying white supremacist ethos ... affects ... the entire world". He warns of a growing 'greening of hate' where northern environmentalists point to "overpopulation as the cause of apocalyptic environmental degradation and advocate control of immigration - indeed coercive population control itself - to protect the ('pure' and 'natural') environment." Ironically, these very same communities depend on the care work, hard labour and other services provided by migrants in their homes and communities (MacAskill, 2007).

The questions such images raise are fraught. Is the question, Crosby asks, about open borders? If so, why can capital, goods and knowledge flow freely across borders, and not people? She goes deeper into this question to touch on the fears rooted in myths of the nation:

\footnotetext{
"The historical processes of inclusion and exclusion that have constructed the modern nation-state, particularly in countries of the North, have led to the definition of who is permitted to belong to, and participate within, the national space. And these processes have always been inherently racialized, a historical fact often papered over in 'supply and demand' descriptions of immigration policy."
}

Xenophobia is not only a North-South phenomenon, but is evolving also within southern communities - for instance, within South Africa, which is a prime destination for many African other non-South African blacks (see http:/ www.theatlantic.com/doc/prem/200111/nixon, accessed 6 September 2007). In East Africa, the antipathy towards Somalis is well documented and politicians and other demagogues push the fear of the 'other', particularly in the context of increased 'insecurity' and shrinking resources.

The fourth message of the journal is that none of these issues are easy or somehow solvable by sound economics or good governance or social policy. Migration is not new, and neither is racism, violence or exploitation. What perhaps is new is that we are in a world that is more and more interconnected with vast numbers of people, information and goods on the move. Via Internet, cheap travel and intensive marketing and increased consumerism for some and exploitation for others, we hear, see and feel vividly a global world with its stark levels of inequality, violence and uncertainties not far from the surface. We struggle with the realities of difference and the 'other' in our own lives; whether we are migrants or tourists, cybersurfers or newspaper readers, workers or consumers and the layers in between, all of us live far more global lives.

As an Australian now living in Italy, I can only agree with Crosby that "migration is about relationships across borders'. In a globalized world, there are more and more crossings of different borders. The baggage around the term migration itself needs to be questioned. The ebbs and flows of people have been an enduring feature of many of our histories and places. This fluidity of populations is not captured by the notion of migration that implies a one-way movement between identifiable territories (Underhill-Sem, 2004).

Development and migration policies are not so much about 'us' and 'them' but about all our globalized lives interlinked within the complexities of global capital. The economic and social factors that are leading to 200 million migrants in search of another life are linked to the wider structures and policies that are also determining development policies. They are inextricably linked through the workings of the global market and through the continued question of what living in this transnational world means for our sense of citizenship, community, belonging and home. 


\section{Harcourt: Editorial: Beyond Us and Them}

\section{References}

Balakrishnan, Angela and Pui-Guan Man (2007) 'The Best Migrate, The Rest Suffer', The Guardian Weekly 03.08.07: 42.

MacAskill, Ewen (2007) 'Communities Get Tough With the Illegal Immigrants They Need But Don't Want', The Guardian Weekly 31.08.07: 9.

Marshall, Phil and Susu Thatun (2005) 'Miles Away: The trouble with prevention in the greater Mekong region', in Kamala Kempadoo with Jyoti Sanghera and Bandana Pattanaik (eds.) Trafficking and Prostitution Reconsidered: New perspectives on migration, sex work and human rights, Boulder, $\mathrm{CO}$ and London: Paradigm Publishers.

Monzini, Paola (2005) SexTraffic, London: Zed Books.

Underhill-Sem, Yvonne (2004) 'Fertility of Mobility: Impulses from Hawaii', Geojournal 59: 55-8.

Youngs, Gillian (2007) Global Political Economy in the Information Age: Power and inequality, London and New York: Routledge Taylor and Francis Group. 